\title{
Rail Device
}

National Cancer Institute

\section{Source}

National Cancer Institute. Rail Device. NCI Thesaurus. Code C50130.

A bar designed for support, attachment, guidance, or protection from falling. 